Popper H. Shaffner F, eds. Progress in liver disease. Vol 3. New York: Grune and Stratton, 1970:282-98.

10 Williams R. Management of acute liver failure. Postgrad Med J 1988;64: 769-71.

11 O'Grady JG, Williams R. Management of acute liver failure. Schweiz Med Wochensichr 1986;116:541-4.

12 O'Grady JG, Williams R. Acute liver failure. Baillieres Clin Gastroenterol 1989:3:75-89.

13 O'Grady J, Alexander (jJ.M, Havllar KM. Williams R. Early indicators of prognosis in fulminant hepatic failure. Gastroenterologv 1989;97:439-45.

14 Harrison PM. O'Grady JG, Keays R, Alexander GJM, Williams R. Serial prothrombin time as prognostic indicator in paracetamol-induced fulminant hepatic failure. BMF 1990;301:964-6.

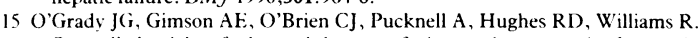
Controlled trials of charcoal hemoperfusion and prognostic factors in fulminant hepatic failure. Gastroenterology 1988;94:1186-92

16 Knaus WA, Draper EA, Wagner EP, Zimmerman JE. Prognosis in acute organ-system failure. Ann Surg 1985;202:685-93.

17 Bihari DJ, Gimson AE, Williams R. Cardiovascular, pulmonary and renal complications of fulminant hepatic failure. Semin Liver Dis 1986;6:119-28.

18 Harrison PM, Wendon JA, Gimson AES, Alexander GJM, Williams R.
Improvement by acetvlcysteine of hemodynamics and oxygen transport in fulminant hepatic failure. $N$ Engl F Med 1991;324:1852-7.

19 De Leve LD, Kaplowitz N. Hepatic endothelial cells as a target for acetaminophen (APAP) toxicity [abstract]. Hepatology 1990;12:A1009.

20 Tirmenstein MA, Nelson SD. Acetaminophen-induced oxidation of protein thiols. Contribution of impaired thiol-metabolizing enzymes and the hiols. Contribution of impaired thiol-metabolizing enzymes

21 Haenen G. Reduction of $\beta$-adrenoceptor function by oxidative stress in the heart. In: Thiols in oxidative stress, some implications for catecholamine toxicity. Amsterdam: Free University Press, 1989:151-66. (Dissertation.)

22 Artman M, Olson RD, Boucek RJ, Boerth RC. Depression of contractility in isolated rabbit myocardium following exposure to iron: role of free radicals. Toxicol Appl Pharmacol 1984;72:324-32.

23 Aruoma O, Halliwell B, Hoey B, Butler J. The antioxidant action of $\mathrm{N}$-acetylcysteine: its reaction with hydrogen peroxide, hydroxyl radical, superoxide, and hypochlorous acid. Free Radic Biol Med 1989;6:593-7.

24 Prescott L, Donovan J, Jarvie D, Proudfoot A. The disposition and kinetics of intravenous $\mathrm{N}$-acetylcysteine in patients with paracetamol overdosage. Eur f Clin Pharmacol 1989;37:501-6.

(Accepted 6 August 1991)

\title{
Use of psychiatric services by patients in a general hospital
}

\author{
Richard Mayou, Valerie Seagroatt, Michael Goldacre
}

\begin{abstract}
Objective-To identify physical disorders associated with increased rate of use of psychiatric services.

Design-Retrospective analysis of routine abstracts of general hospital inpatient records linked with those of psychiatric care, for inpatients with physical disorders with possible psychiatric associations and for controls.

Setting-Oxfordshire health district.

Subjects - Inpatients aged 15-64 years discharged from general hospitals during 1975-85 with a diagnosis among 14 selected diagnostic groups (including potentially life threatening conditions, chronic disabling diseases, and non-specific symptomatic conditions) and control inpatients with acute conditions.
\end{abstract}

Main outcome measures-Observed and expected numbers of patients receiving psychiatric care.

Results-Observed use of psychiatric services before and after index admission was close to that expected for controls. For most other diagnoses the observed use was significantly increased in the year preceding and that subsequent to the admission. For four diagnostic groups it was significantly greater in the year after admission than in that before (acute myocardial infarction (ratio before to after $2 \cdot 17,95 \%$ confidence interval 1.5 to 3.3$)$, cancer $(2.05,1.7$ to $2 \cdot 5)$, diabetes mellitus $(1.89,1.4$ to $2 \cdot 9)$, and chest pain $(1.78,1.3$ to 2.4$)$ ). During four years after the admission the use of psychiatric services was signifcantly higher than in the general population for nonspecific symptomatic conditions (observed/expected: abdominal pain $1 \cdot 7$, chest pain $2 \cdot 0$, and headache $4 \cdot 2$ ), cirrhosis of the liver (10.4), and fractures in road accidents and other fractures $(1 \cdot 3,1 \cdot 6)$.

Conclusions-More patients with certain physical conditions used psychiatric services. Alternative methods of service delivery may be needed, especially for disabling chronic physical illness, alcohol related disorders, and non-specific symptomatic conditions.

\section{Introduction}

Associations between psychiatric disorder and physical symptoms and conditions are evident in the general population, ${ }^{1-3}$ in people attending primary care services, ${ }^{4}$ and in patients in general hospitals. ${ }^{5.9}$ Explanations for such associations include psychiatric disorder as a reaction to physical illness, psychiatric disorder presenting with somatic symptoms, physical complications of psychiatric disorders, and aetiological or other risk factors common to both psychiatric and physical disorders. Other important factors which may result in associations between disorders include illness and consultation behaviour ${ }^{4}$ and referral and admission practice $^{7.4}$ and the possibility that people with two disorders may be more likely to receive specialist care than those with either disorder alone. ${ }^{10}$

Psychiatric illness among patients in general hospitals is important, both because it can be a persistent disability and because it is associated with poor compliance with medical treatment and extra demands on medical resources. ${ }^{511-13}$ Unfortunately, such illness is not always recognised and, if recognised, treated. Few patients are referred to specialist psychiatric consultation services within general hospitals. ${ }^{14} 15$

We considered that it would be useful to quantify the use of psychiatric services by patients in general hospitals and to identify particular types of physical problem associated with increased rate of use of psychiatric services. Such information could have implications for the delivery of psychiatric and other psychological services and may also provide evidence of aetiological associations between physical and psychiatric disorders.

We used abstracts of general hospital inpatient records linked with abstracts of psychiatric care to study the use of psychiatric services by patients in general hospitals with a diagnosis on discharge among 14 groups of chosen diagnoses. The use of psychiatric services was compared, firstly, with that by the general population in the same health district and, secondly, with a group of patients in general hospitals selected as controls. The diagnoses were chosen to illustrate physical conditions which may be life threatening and distressing (for example, myocardial infarction and cancer); those which might in some patients be an expression of psychiatric disorder (for example, chest pain, abdominal pain, and headache); those in which physical disorder may be the consequence of psychiatric disorder (for example, cirrhosis after chronic alcohol problems); and those in which associations between physical and psychiatric conditions may exist but whose nature may be more complex.

\section{Patients and methods}

The Oxford record linkage study consists of brief abstracts of inpatient general and psychiatric hospitals, 
patients' records, and death records. ${ }^{16} 17$ For many years these data have been collected in the Oxford region such that records relating to the same person can be linked. Since 1974 the study has also routinely included data on outpatient and other non-inpatient psychiatric care for the Oxfordshire district (population about 500000 ). Our analysis was confined to people aged 15-64 who were resident and treated in the Oxfordshire district.

Patients' records were included in the study if they had an admission to a general hospital in the Oxfordshire district with a main diagnosis falling into one of the 14 chosen clinical diagnostic groups (table I). (We chose these groups before knowledge of the results of analysis.) We included a control group of patients who were admitted to hospital with acute, short term conditions which we considered unlikely to be associated substantially with psychiatric disorders. This group comprised people with an admission for inguinal hernia, appendicitis, lipoma, varicose veins, sebaceous cyst, renal stones, nasal polyps, and deflected nasal septum and dental patients. We confined our analysis to those patients discharged during 1975-85 to give a minimum of one year before and at least one year after the index admission to determine whether any episode of psychiatric care had occurred. All episodes of psychiatric care in the relevant periods were included, thus the results include inpatient care, outpatient care, day care, domiciliary visits, and liaison care undertaken by consultant psychiatrists or their junior medical staff. We also checked the record linkage files back to 1968 to ensure that no admission for the physical diagnoses had occurred in each of the patients in the preceding years - that is, for at least seven years. Nevertheless, some patients might have migrated to Oxfordshire after having been treated for the condition outside the district.

Annual age specific and sex specific rates for psychiatric contacts in the Oxfordshire population as a whole were applied to each age-sex group of each group of patients with physical disorders to give the "expected" number of people who would have been receiving psychiatric care each year if the rates in the general population had prevailed in the group. The calculations were performed with a computer program which adjusted for differing lengths of follow up due to deaths or to censoring at the end of the study period. ${ }^{18}$ The rates for psychiatric care did not take into account migration to or from the district and so would be underestimated by about $2-5 \%$ a year. ${ }^{19}$

We assessed the significance of the difference between the observed and expected numbers of patients receiving psychiatric care with the conventional $\chi^{2}$ statistic with the continuity correction. This statistic is based on the assumption that the observed number follows a Poisson distribution. Confidence intervals for the ratios of observed to expected numbers of patients were calculated with Byar's approximation..$^{20}$ The significance of the difference between the ratios of observed to expected numbers of patients in the years before and after the index admission was assessed by a $\chi^{2}$ statistic with one degree of freedom, ${ }^{20}$ equivalent to that used for comparing two standardised mortality ratios, and the continuity correction was again applied. To obtain some measure of the magnitude of these differences the ratios of observed to expected numbers for the year after the index admission was expressed relative to those for the year before, and confidence intervals for these ratios were calculated. The significance of the trend in the ratios of observed to expected numbers in the four years after the index admission was assessed by the $\chi^{2}$ statistic for trend with one degree of freedom..$^{20}$

\section{Results}

Psychiatric care in the year before and after index admission

Table I compares the observed number of patients in each diagnostic group who received psychiatric care in the year preceding the index admission and in the subsequent year with the expected numbers (based on the population rates). The observed numbers were very close to those expected in the control group. For all other patients, except those with myocardial infarction or non-specific viral infection, psychiatric care in the year before the index admission was significantly more common than expected. In the year after the index admission the numbers of patients receiving psychiatric care in all groups (except the

TABLE I-Observed and expected numbers of patients receiving psychiatric care in the year before and after index admission and ratios of observed to expected numbers and of ratios for year after relative to year before, by diagnostic group

\begin{tabular}{|c|c|c|c|c|c|c|c|c|}
\hline $\begin{array}{l}\text { Clinical condition } \\
\text { (ICD } 9 \text { codes) }\end{array}$ & $\begin{array}{c}\text { Total No of } \\
\text { patients }\end{array}$ & $\begin{array}{l}\text { Period relative to } \\
\text { index admission }\end{array}$ & Observed & Expected & $\begin{array}{l}\text { Observed/ } \\
\text { expected }\end{array}$ & $\begin{array}{l}95 \% \text { Confidence } \\
\text { interval }\end{array}$ & $\begin{array}{l}\text { Ratio after to } \\
\text { ratio before }\end{array}$ & $\begin{array}{l}95 \% \text { Confidence } \\
\text { interval }\end{array}$ \\
\hline Control groups $(214,454,470,471$, & 17333 & Before & 174 & $160 \cdot 8$ & $1 \cdot 1$ & 0.9 to 1.3 & 1 & \\
\hline $520-1,540-3,550,592,706 \cdot 2)$ & & After & 161 & $158 \cdot 3$ & 1.0 & 0.9 to $1 \cdot 2$ & 0.94 & 0.8 to 1.1 \\
\hline Acute myocardial infarction $(410)$ & 2289 & Before & 22 & $18 \cdot 4$ & $1 \cdot 2$ & 0.8 to 1.8 & 1 & \\
\hline & & After & 40 & $15 \cdot 4$ & $2 \cdot 6$ & 1.9 to 3.5 & $2 \cdot 17^{\star \star}$ & 1.5 to 3.3 \\
\hline \multicolumn{9}{|l|}{ Fractures $(800-829):$} \\
\hline In road traffic accidents & 1546 & Before & 23 & $13 \cdot 0$ & 1.8 & $1 \cdot 1$ to $2 \cdot 7$ & 1 & \\
\hline & & After & 30 & $12 \cdot 6$ & $2 \cdot 4$ & 1.6 to 3.4 & $1 \cdot 34$ & $0 \cdot 9$ to $2 \cdot 1$ \\
\hline \multirow[t]{2}{*}{ Other } & 4496 & Before & 99 & $38 \cdot 8$ & $2 \cdot 6$ & $2 \cdot 1$ to $3 \cdot 1$ & 1 & \\
\hline & & After & 101 & $37 \cdot 7$ & $2 \cdot 7$ & $2 \cdot 2$ to $3 \cdot 3$ & 1.05 & 0.9 to 1.3 \\
\hline \multirow[t]{2}{*}{ Stroke (430-6) } & 1448 & Before & 28 & $12 \cdot 1$ & $2 \cdot 3$ & 1.5 to 3.3 & $i$ & \\
\hline & & After & 29 & $8 \cdot 9$ & $3 \cdot 3$ & $2 \cdot 2$ to $4 \cdot 7$ & $1 \cdot 41$ & 0.8 to 2.0 \\
\hline \multirow[t]{2}{*}{ Non-specific viral infections $(079)$} & 292 & Before & 4 & $2 \cdot 8$ & 1.4 & $0 \cdot 4$ to $3 \cdot 6$ & 1 & \\
\hline & & After & 10 & $2 \cdot 7$ & $3 \cdot 6$ & 1.7 to 6.7 & $2 \cdot 57$ & 0.9 to $8 \cdot 8$ \\
\hline \multirow[t]{2}{*}{ Cancer (140-208) } & 5848 & Before & 91 & $51 \cdot 2$ & 1.8 & $1 \cdot 4$ to $2 \cdot 2$ & 1 & \\
\hline & & After & 137 & $37 \cdot 6$ & 3.6 & $3 \cdot 1$ to $4 \cdot 3$ & $2 \cdot 05^{\star \star}$ & 1.7 to 2.5 \\
\hline \multirow[t]{2}{*}{ Diabetes mellitus (250) } & 1276 & Before & 22 & $11 \cdot 4$ & 1.9 & $1 \cdot 2$ to 2.9 & 1 & \\
\hline & & After & 39 & $10 \cdot 7$ & $3 \cdot 6$ & $2 \cdot 6$ to $5 \cdot 0$ & $1 \cdot 89^{\star}$ & 1.4 to 2.9 \\
\hline \multirow[t]{2}{*}{ Multiple sclerosis $(340)$} & 326 & Before & 9 & $3 \cdot 3$ & $2 \cdot 7$ & $1 \cdot 2$ to $5 \cdot 1$ & 1 & \\
\hline & & After & 14 & $3 \cdot 1$ & $4 \cdot 6$ & $2 \cdot 5$ to $7 \cdot 7$ & 1.69 & 0.8 to 3.8 \\
\hline \multirow[t]{2}{*}{ Cirrhosis of liver (571) } & 342 & Before & 47 & $3 \cdot 0$ & $15 \cdot 5$ & $11 \cdot 4$ to $20 \cdot 6$ & 1 & \\
\hline & & After & 47 & $2 \cdot 4$ & $19 \cdot 3$ & $14 \cdot 2$ to $25 \cdot 7$ & $1 \cdot 25$ & 0.9 to 1.7 \\
\hline \multirow[t]{2}{*}{ Abdominal pain $(789 \cdot 0)$} & 5441 & Before & 167 & $53 \cdot 0$ & $3 \cdot 2$ & $2 \cdot 7$ to $3 \cdot 7$ & 1 & \\
\hline & & After & 181 & $51 \cdot 1$ & 3.5 & $3 \cdot 0$ to $4 \cdot 1$ & $1 \cdot 12$ & 0.9 to 1.6 \\
\hline \multirow[t]{2}{*}{ Chest pain $(786 \cdot 5)$} & 1568 & Before & 38 & $14 \cdot 2$ & $2 \cdot 7$ & 1.9 to 3.7 & 1 & \\
\hline & & After & 63 & $13 \cdot 2$ & $4 \cdot 8$ & $3 \cdot 7$ to $6 \cdot 1$ & $1 \cdot 78^{\star \star}$ & $1 \cdot 3$ to $2 \cdot 4$ \\
\hline \multirow[t]{2}{*}{ Headache $(784 \cdot 0)$} & 303 & Before & 12 & 2.9 & $4 \cdot 1$ & $2 \cdot 1$ to $7 \cdot 2$ & 1 & \\
\hline & & After & 15 & $2 \cdot 7$ & $5 \cdot 6$ & $3 \cdot 1$ to $9 \cdot 2$ & $1 \cdot 36$ & 0.7 to 2.8 \\
\hline \multirow[t]{2}{*}{ Disorders of menstruation (626) } & 5856 & Before & 108 & $66 \cdot 6$ & 1.6 & 1.3 to 2.0 & 1 & \\
\hline & & After & 108 & $63 \cdot 5$ & $1 \cdot 7$ & 1.4 to $2 \cdot 1$ & 1.05 & 0.9 to 1.3 \\
\hline \multirow[t]{2}{*}{ Irritable bowel syndrome $(564 \cdot 1)$} & 274 & Before & 11 & 2.8 & 3.9 & $2 \cdot 0$ to $7 \cdot 0$ & 1 & \\
\hline & & After & 20 & $2 \cdot 6$ & $7 \cdot 7$ & 4.7 to 11.8 & 1.96 & $1 \cdot 0$ to $4 \cdot 1$ \\
\hline
\end{tabular}


TABLE II-Observed numbers of patients receiving psychiatric care in each of four years after index admission and ratio of observed to expected numbers

\begin{tabular}{|c|c|c|c|c|c|}
\hline Diagnostic group & $\begin{array}{l}\text { Years after index } \\
\text { admission }\end{array}$ & Observed & $\begin{array}{l}\text { Observed/ } \\
\text { expected }\end{array}$ & $\begin{array}{l}95 \% \text { Confidence } \\
\text { interval }\end{array}$ & $\begin{array}{l}\gamma^{2} \text { For trend } \\
(\mathrm{df}=1)\end{array}$ \\
\hline Controls & $\begin{array}{l}<1 \\
1-2 \\
2-3 \\
3-4\end{array}$ & $\begin{array}{l}161 \\
151 \\
110 \\
112\end{array}$ & $\begin{array}{l}1 \cdot 0 \\
1 \cdot 1 \\
1.9 \\
1 \cdot 1\end{array}$ & $\begin{array}{l}0.9 \text { to } 1.2 \\
0.9 \text { to } 1.3 \\
0.8 \text { to } 1.1 \\
0.9 \text { to } 1.4\end{array}$ & $0 \cdot 1$ \\
\hline Acute myocardial infarction & $\begin{array}{l}<1 \\
1-2 \\
2-3 \\
3-4\end{array}$ & $\begin{array}{r}40 \\
21 \\
10 \\
6\end{array}$ & $\begin{array}{l}2 \cdot 6 \\
1 \cdot 6 \\
0 \cdot 9 \\
0 \cdot 7\end{array}$ & $\begin{array}{l}1.9 \text { to } 3.5 \\
1.0 \text { to } 2.5 \\
0.4 \text { to } 1.7 \\
0.2 \text { to } 1.5\end{array}$ & $16 \cdot 4^{\star \star}$ \\
\hline $\begin{array}{l}\text { Fractures: } \\
\text { In road traffic accidents }\end{array}$ & $\begin{array}{l}<1 \\
1-2 \\
2-3 \\
3-4\end{array}$ & $\begin{array}{l}30 \\
22 \\
14 \\
12\end{array}$ & $\begin{array}{l}2 \cdot 4 \\
1.9 \\
1 \cdot 3 \\
1 \cdot 3\end{array}$ & $\begin{array}{l}1.6 \text { to } 3.4 \\
1.2 \text { to } 2 \cdot 9 \\
0.7 \text { to } 2 \cdot 2 \\
0.7 \text { to } 2 \cdot 2\end{array}$ & $5 \cdot 0^{\star}$ \\
\hline Other & $\begin{array}{l}<1 \\
1-2 \\
2-3 \\
3-4\end{array}$ & $\begin{array}{r}101 \\
61 \\
63 \\
40\end{array}$ & $\begin{array}{l}2 \cdot 7 \\
1.9 \\
2 \cdot 2 \\
1 \cdot 6\end{array}$ & $\begin{array}{l}2 \cdot 2 \text { to } 3 \cdot 1 \\
1.4 \text { to } 2 \cdot 4 \\
1 \cdot 7 \text { to } 2 \cdot 8 \\
1.1 \text { to } 2 \cdot 2\end{array}$ & $6 \cdot 2^{\star}$ \\
\hline Stroke & $\begin{array}{l}<1 \\
1-2 \\
2-3 \\
3-4\end{array}$ & $\begin{array}{l}29 \\
17 \\
18 \\
15\end{array}$ & $\begin{array}{l}3 \cdot 3 \\
2 \cdot 2 \\
2 \cdot 8 \\
2 \cdot 8\end{array}$ & $\begin{array}{l}2.2 \text { to } 4.7 \\
1.3 \text { to } 3.6 \\
1.6 \text { to } 4.4 \\
1.5 \text { to } 4.5\end{array}$ & $0 \cdot 2$ \\
\hline Non-specific viral infections & $\begin{array}{l}<1 \\
1-2 \\
2-3 \\
3-4\end{array}$ & $\begin{array}{r}10 \\
9 \\
4 \\
3\end{array}$ & $\begin{array}{l}3 \cdot 7 \\
3 \cdot 4 \\
1 \cdot 7 \\
1 \cdot 4\end{array}$ & $\begin{array}{l}1.7 \text { to } 6.7 \\
1.6 \text { to } 6.5 \\
0.4 \text { to } 4.2 \\
0.3 \text { to } 4.2\end{array}$ & $3 \cdot 3$ \\
\hline Cancer & $\begin{array}{l}<1 \\
1-2 \\
2-3 \\
3-4\end{array}$ & $\begin{array}{r}137 \\
58 \\
32 \\
16\end{array}$ & $\begin{array}{l}3 \cdot 6 \\
2 \cdot 2 \\
1 \cdot 5 \\
0 \cdot 9\end{array}$ & $\begin{array}{l}3.1 \text { to } 4.3 \\
1.6 \text { to } 2.8 \\
1.0 \text { to } 2.1 \\
0.5 \text { to } 1.5\end{array}$ & $44 \cdot 6^{\star \star}$ \\
\hline Diabetes mellitus & $\begin{array}{l}<1 \\
1-2 \\
2-3 \\
3-4\end{array}$ & $\begin{array}{l}39 \\
17 \\
19 \\
11\end{array}$ & $\begin{array}{l}3 \cdot 6 \\
1.8 \\
2 \cdot 3 \\
1.5\end{array}$ & $\begin{array}{l}2.6 \text { to } 5.0 \\
1.0 \text { to } 2.8 \\
1.4 \text { to } 3.6 \\
0.8 \text { to } 2.7\end{array}$ & $6 \cdot 8^{\star \star}$ \\
\hline Multiple sclerosis & $\begin{array}{l}<1 \\
1-2 \\
2-3 \\
3-4\end{array}$ & $\begin{array}{r}14 \\
7 \\
3 \\
3\end{array}$ & $\begin{array}{l}4 \cdot 6 \\
2 \cdot 6 \\
1 \cdot 2 \\
1 \cdot 4\end{array}$ & $\begin{array}{l}2.5 \text { to } 7 \cdot 7 \\
1.0 \text { to } 5.3 \\
0.3 \text { to } 3.6 \\
0.3 \text { to } 4.2\end{array}$ & $6 \cdot 2^{\star}$ \\
\hline Cirrhosis of liver & $\begin{array}{l}<1 \\
1-2 \\
2-3 \\
3-4\end{array}$ & $\begin{array}{l}47 \\
20 \\
13 \\
14\end{array}$ & $\begin{array}{r}19 \cdot 3 \\
9 \cdot 1 \\
7 \cdot 6 \\
10 \cdot 4\end{array}$ & $\begin{array}{r}14 \cdot 2 \text { to } 25 \cdot 7 \\
5 \cdot 6 \text { to } 14 \cdot 1 \\
4 \cdot 0 \text { to } 13 \cdot 0 \\
5 \cdot 7 \text { to } 17 \cdot 4\end{array}$ & $8 \cdot 3^{\star \star}$ \\
\hline Abdominal pain & $\begin{array}{l}<1 \\
1-2 \\
2-3 \\
3-4\end{array}$ & $\begin{array}{r}181 \\
96 \\
76 \\
55\end{array}$ & $\begin{array}{l}3 \cdot 5 \\
2 \cdot 1 \\
1.9 \\
1 \cdot 7\end{array}$ & $\begin{array}{l}3.0 \text { to } 4 \cdot 1 \\
1 \cdot 7 \text { to } 2 \cdot 6 \\
1.5 \text { to } 2 \cdot 4 \\
1.3 \text { to } 2 \cdot 2\end{array}$ & $31 \cdot 4^{\star \star}$ \\
\hline Chest pain & $\begin{array}{l}<1 \\
1-2 \\
2-3 \\
3-4\end{array}$ & $\begin{array}{l}63 \\
30 \\
23 \\
15\end{array}$ & $\begin{array}{l}4 \cdot 8 \\
2 \cdot 6 \\
2 \cdot 4 \\
2 \cdot 0\end{array}$ & $\begin{array}{l}3.7 \text { to } 6.1 \\
1.7 \text { to } 3.7 \\
1.5 \text { to } 3.6 \\
1.1 \text { to } 3.3\end{array}$ & $13 \cdot 7^{\star \star}$ \\
\hline Headache & $\begin{array}{l}<1 \\
1-2 \\
2-3 \\
3-4\end{array}$ & $\begin{array}{r}15 \\
11 \\
6 \\
7\end{array}$ & $\begin{array}{l}5 \cdot 6 \\
4 \cdot 6 \\
3 \cdot 0 \\
4 \cdot 2\end{array}$ & $\begin{array}{l}3.1 \text { to } 9.2 \\
2.3 \text { to } 8.3 \\
1.1 \text { to } 6.6 \\
1.7 \text { to } 8.6\end{array}$ & $1 \cdot 0$ \\
\hline Disorders of menstruation & $\begin{array}{l}<1 \\
1-2 \\
2-3 \\
3-4\end{array}$ & $\begin{array}{r}108 \\
78 \\
80 \\
52\end{array}$ & $\begin{array}{l}1 \cdot 7 \\
1 \cdot 3 \\
1 \cdot 5 \\
1 \cdot 1\end{array}$ & $\begin{array}{l}1.4 \text { to } 2.1 \\
1.1 \text { to } 1.7 \\
1.2 \text { to } 1.9 \\
0.8 \text { to } 1.4\end{array}$ & $5 \cdot 4^{\star}$ \\
\hline Irritable bowel syndrome & $\begin{array}{l}<1 \\
1-2 \\
2-3 \\
3-4\end{array}$ & $\begin{array}{r}20 \\
6 \\
6 \\
2\end{array}$ & $\begin{array}{l}7 \cdot 7 \\
2 \cdot 7 \\
3 \cdot 2 \\
1 \cdot 3\end{array}$ & $\begin{array}{l}4 \cdot 7 \text { to } 11 \cdot 8 \\
1 \cdot 0 \text { to } 5 \cdot 9 \\
1 \cdot 2 \text { to } 7 \cdot 0 \\
0 \cdot 1 \text { to } 4 \cdot 8\end{array}$ & $9 \cdot 2^{\star}$ \\
\hline
\end{tabular}

$\star \star \star$ Significant at $5 \%$ and $1 \%$ levels respectively. each of the four years after the index admission. In the control group none of the ratios for the four years differed significantly from 1 and no trend was found. The ratios for patients with stroke also showed little change, although they were all significantly higher than 1. The other groups all showed a decline, which was significant for all but the non-specific viral infections and headache (in which the power of the test for trend was limited by the few patients in these groups). By the fourth year the rates of psychiatric care $\overrightarrow{\vec{F}}$ for most of the acute and chronic clinical conditions had declined to a level not significantly different from $\bar{C}$ that of the population as a whole. In contrast, in the groups for abdominal pain, chest pain, and headache $\frac{D}{\vec{D}}$ and cirrhosis and fractures other than in road traffic $\stackrel{\mathbb{Q}}{\Omega}$ accidents these rates were still significantly higher than those in the general population.

\section{Discussion}

Psychiatric research, both epidemiological re- 3 search $^{1-6}$ and studies of individual patients, has $\omega$ examined psychiatric comorbidity but has generally $\omega$ paid little attention to the use of services. Research on $\varnothing$ individual disorders ${ }^{1.9}$ and some general evidence 8 suggests a greater than expected use of psychiatric services by people with physical disease, but there 융 has been no quantitative evidence from large scale population based studies.

Medical record linkage provides a method for $N$ studying the use of psychiatric services by patients $O$ admitted from a defined population to general hospitals for a range of medical conditions and enables comparisons to be made between these rates and those for the resident population.

The considerable use of psychiatric services before and after the index admission to general hospital by patients with symptom diagnoses is consistent with descriptive and prospective studies of patients with specific symptoms, which suggest that in some patients such symptoms are wholly or partially due to psychiatric disorder, such as anxiety or depression..$^{21-23}$ In some patients the psychiatric disorder was recognised and led to referral before the general hospital admission. In others, psychiatric care followed discharge from hospital without a specific physical cause being found. Such referral is often delayed.

Psychiatric referral to the general hospital consultation service during the index admission accounted for only a small part of total use of the psychiatric service during the first subsequent year. Most referrals would have been made by general practitioners and not coordinated with any continuing medical care.

The differences between the conditions that we studied are in part explicable by clear differences in the nature and threat of the physical conditions and in part $N$ by illness and referral behaviours. More detailed study of patients with particular disorders will be necessary to understand the precise associations and their implications for clinical care.

The costs of care of the extra use of psychiatric $\varrho$ services by people with physical illnesses must be substantial. It would be sensible to examine alternative, $\overrightarrow{0}$ and perhaps more collaborative methods of service $\mathbb{D}$ delivery in which continuing medical and psychiatric management could be more closely coordinated. Our findings suggest that we should concentrate on disabling chronic physical illness, alcohol related disorders, and unexplained physical symptoms. Routine screening in medical settings and wide availability of simple psychosocial help would enable most psychological care to be provided by non-medical members of general hospital and general practice teams. At the same time easy access to specialist 
services combining medical and psychiatric expertise is needed.

I Eastwood R, Trevelyan MH. Relationship between physical and psychological disorder. Psychol Med 1972:2:363-7.

2 Wells KB, Golding JM, Burnam MA. Affective, substance use, and anxiety disorders in persons with arthritis, diabetes, heart disease, high blood pressure, or chronic lung conditions. Gen Hosp Psychiatry 1989;11:320-7.

3 Wells KB, Golding JM, Burnam MA. Chronic medical conditions in a sample of the general population with anxiety, affective, and substance use disorders. Am $\mathcal{F}$ Psychiatry 1989;146:1440-6.

4 Goldberg D, Huxley P. Mental illness in the community. London: Tavistock, 1980

5 Stewart AL, Greenfield S, Wells K, Rogers WH, Berry SD, Hays RD, et al. Functional status and well-being of patients with chronic conditions. $\mathcal{F} A M A$ 1989;262:907-13.

6 Mayou RA, Hawton KE. Psychiatric disorder in the general hospital. $\mathrm{Br} f$ Psychiatry 1986;149:172-96.

Regier DA, Goldberg ID, Taube CA. The de facto US mental health services system. Arch Gen Psychiatry 1978;35:685-93.

8 Kessler LG, Burns BJ, Shapiro S, Tischler GL, George LK, Hough RL. Psychiatric diagnoses of medical service users: evidence from the epidemiologic catchment area program. Am F Public Health 1987;77:18-24.

9 lo in JR Steins Use of general medical care services by persons with mental disorders. Arch Use of general medical care

10 Berkson J. Limitations of the application of fourfold table analysis to hospital data. Biometrics Bulletin 1946;2:47-53.

11 Barsky AJ, Wyshak G, Klerman GL. Medical and psychiatric determinants of out-patient medical utilization. Med Care 1986;24:548-60.
12 Fulop G, Strain JJ, Fahs MC, Hammer JS, Lyons JS. Medical disorders associated with psychiatric comorbidity and prolonged hospital stay. Hosp Community Psychiatry 1989;40:80-2.

13 Mayou RA, Hawton K, Feldman E. What happens to medical patients with psychiatric disorder? F Psychosom Res 1988; 32:541-9.

14 Wallen J, Pincus HA, Goldman HH, Marcus SE. Psychiatric consultations in short-term general hospitals. Arch Gen Psychiatry 1987;44:163-8.

15 Hengeveld MW, Rooymans HGM, Vecht-van den Bergh R. Psychiatric consultations in a Dutch university hospital: a report on 1814 referrals, compared with a literature review. Gen Hosp Psychiatry 1984;6:271-9.

16 Acheson ED. Medical record linkage. Oxford: Oxford University Press, 1967.

17 Gill LE, Baldwin JA. Methods and technology of record linkage: some practical considerations. In: Baldwin JA, Acheson ED, Graham WJ, eds. Textbook of medical record linkage. Oxford: Oxford University Press, 1987;3:39-54.

18 Colman M, Douglas A, Herman C, Peto J. Cohort study analysis with a FORTRAN computer programme. Int 7 Epidemiol 1986;15:134-7.

19 Devis T. Population movements measured by the NHS central register. Population Trends 1984;36:18-24.

20 Breslow NE, Day NE. Statistical methods in cancer research II-the design and analysis of cohort studies. Lyons: International Agency for Research on
Cancer, 1987:68-9, 94-6.

21 Rang EH, Fairbain AS, Acheson ED. An enquiry into the evidence and prognosis of undiagnosed abdominal pain treated in hospital. British foumal prognosis of undiagnosed abdominal pain treated
of Preventive and Social Medicine 1970;24:47-51.

22 Fitzpatrick RM, Hopkins A. Referrals to neurologists for headaches not due to structural disease. $\mathcal{F}$ Neurol Neurosurg Psychiatry 1987;44:1061-7.

23 Mayou RA. Atypical non-cardiac chest pain. I Psychosom Res 1989;33: $393-406$

(Accepted 23 fuly 199I)

\section{Passive smoking and otitis media with effusion}

\section{G S Barr, A P Coatesworth}

\section{Department of \\ Otolaryngology, Queen \\ Elizabeth Hospital, \\ Birmingham B15 2TH \\ G S Barr, FRCS, senior registrar}

A P Coatesworth, MB, senior

house officer

Correspondence to:

Mr G S Barr, Department of Otolaryngology, Walsgrave

Hospital, Coventry

CV2 2DX.

BMF 1991;303:1032-3
Otitis media with effusion is reported to occur in over $80 \%$ of children at some stage, but surgery is indicated only when the condition is unresolved after three months. The main underlying causes of otitis media with effusion are eustachian tube malfunction, alteration of the mucociliary system, and nasopharyngeal disproportion. A family history of otitis media in parents or siblings and parental occupation and smoking may also be risk factors. ${ }^{1}$ Hinton $^{2}$ found a higher proportion of parents who smoked among 115 children undergoing surgery for otitis media with effusion than among 35 children attending an orthoptic clinic. A study of 8927 year old schoolchildren in Edinburgh found an association between salivary cotinine concentrations from passive smoking and the presence of tympanometric abnormalities. ${ }^{3}$ Such abnormalities, however, are not necessarily associated with otitis media with effusion.

Otitis media with effusion is diagnosed from the history and by otoscopy, audiometry, and tympanometry. No single entity is completely specific or sensitive and the condition is confirmed by myringotomy. We evaluated the relation between parental smoking habit and the presence of the established condition in a case-control study.

\section{Subjects, methods, and results}

In all, 115 children ( 70 boys, 45 girls; age range 17 months to 11 years 6 months, median 5 years 5 months) from the Cheltenham and Gloucester areas who had otitis media with effusion confirmed by myringotomy were matched according to age (within six months), sex, race, and social class to a control group of healthy children attending the ophthalmology and orthopaedic clinics. The children with otitis media with effusion had had hearing loss for at least three months and had been assessed by otoscopy, tympanometry, and audiometry. The control group had no history of ear problems and normal results on otoscopy and tympanometry with a portable Welch Allyn tympanometer.

The smoking habits of the parents of the children in the two groups were recorded after we had explained the aims of our study to them. Data were compared by McNemar's test for the presence of at least one adult in the household who smoked and whether the mother smoked. The differences between the number of cigarettes smoked by mothers and by all of the adults in the household were calculated by comparing the median values of paired data by the binomial method.

There were 230 adults in the study group and 228 adults in the control group. Seven patients were from socioeconomic class I, 14 from class II, 38 from class III, 43 from class IV, and 13 from class V. Parental smoking habits in the two groups were the same. There were no differences between the median number of cigarettes smoked in the two groups by mothers alone and by all adults in the household ( $95 \%$ confidence interval 0 to 0 cigarettes for both sets of data). The $95 \%$ confidence interval of the difference in proportion of mothers who smoked was -0.08 to $0 \cdot 16$ and that for all adults in the household $-0 \cdot 19$ to 0.05 (McNemar's test; table).

Parental smoking habits among 115 matched pairs of healthy contro children and children with otitis media with effusion

\begin{tabular}{|c|c|c|c|}
\hline \multirow[b]{2}{*}{ Group } & \multirow[b]{2}{*}{ Smokers present } & \multicolumn{2}{|c|}{ No of pairs } \\
\hline & & Mother only & $\begin{array}{l}\text { All adults in } \\
\text { household }\end{array}$ \\
\hline $\begin{array}{l}\text { Otitis media } \\
\text { Control }\end{array}$ & $\left.\begin{array}{l}\text { No } \\
\text { No }\end{array}\right\}$ & 46 & 29 \\
\hline $\begin{array}{l}\text { Otitis media } \\
\text { Control }\end{array}$ & $\left.\begin{array}{c}\text { No } \\
\text { Yes }\end{array}\right\}$ & 22 & 29 \\
\hline $\begin{array}{l}\text { Otitis media } \\
\text { Control }\end{array}$ & $\left.\begin{array}{l}\text { Yes } \\
\text { No }\end{array}\right\}$ & 27 & 21 \\
\hline $\begin{array}{l}\text { Otitis media } \\
\text { Control }\end{array}$ & $\left.\begin{array}{l}\text { Yes } \\
\text { Yes }\end{array}\right\}$ & 20 & 36 \\
\hline Total & & 115 & 115 \\
\hline
\end{tabular}

\section{Comment}

Nasal symptoms, particularly those related to adenoid hypertrophy, are associated with the development of otitis media with effusion. Histamine concentrations in adenoid tissue are proportional to size, but ultrastructural evidence shows that the morphology of adenoid mast cells is the same in children with and without otitis media with effusion (A B Drake-Lee, unpublished data). Exposure to cigarette smoke might induce instability of the mast cell walls and the onset of otitis media with effusion ${ }^{2}$ but our data do not support this hypothesis. 